\title{
Sustainability of Current Account Deficit in Turkey and an Ampirical Analysys for Unit Root Test with Two Structural Breaks
}

\author{
Gülgün Çiğdem ${ }^{1}$ \\ ${ }^{1}$ Department of Banking and Insurance, School of Applied Sciences, Istanbul Gelişim University, Turkey \\ Correspondence: Gülgün Çiğdem, Department of Banking and Insurance, School of Applied Sciences, Istanbul \\ Gelişim University, Cihangir Mahallesi Şehit Jandarma Komando Er Hakan Öner Sk. No:1 Avcılar, Istanbul, \\ Turkey. Tel: 90-212-422-7000. E-mail: gulguncigdem@gmail.com
}

Received: September 28, 2017

Accepted: November 3, 2017 Online Published: November 20, 2017

doi:10.5539/ijef.v9n12p253

URL: https://doi.org/10.5539/ijef.v9n12p253

\begin{abstract}
In this study, Turkey's current account deficit problem between the years 1980-2016 is tested whether it is sustainable or not. For this purpose, the ADF and the PP Unit Root test were applied firstly to the annual current account deficit (CAD)/GDP data from the IMF. Then, Lee Strazicich $(2003,2004)$ Unit Root Tests with two structural breaks was applied. Allowing Lee Strazicich with two structural breaks differs from the Zivot-Andrews (ZA)(1992) and Lumsdaine-Papell (LP) (1997) unit root tests in establishing the basic hypothesis. The ZA and LP unit root tests are based on the basic hypothesis of unit root existence without structural fracture. Based on the Lagrange multiplier proposed by Schmidt and Phillips (1992), LM unit root test with two structural breaks developed by Lee-Strazicich adopted the structural fractured unit root basic hypothesis.

According to the ADF and PP test results, the CAD/GDP series is stationary at the level for both models. According to the LM test results, the unit root null hypothesis could be rejected. It is a stationary process in Turkey. This result is consistent with the ADF and PP test results. Empirical findings obtained from LM unit root test with two structural breaks show that current account deficits in Turkey are sustainable. The fact that the current account deficit is sustainable means the sustainability of external debts. The sustainability of deficit is one of the most emphasized issues especially from the perspective of countries which are dependent on foreign capital to finance their development and also crucial for the global system.
\end{abstract}

Keywords: current account deficit, sustainability, unit root tests, Lee-Strazicich

\section{Introduction}

The body of a current deficit, which is an important indicator that should be monitored during the crisis analysis, maintains its position in the financial agenda in that it is also one of the considerable factors which increase financial fragilities. Current deficit, which reflects the gap between the savings and investments of an economy, is an indicator of the entirety of a country's saving and investment decisions (Edwards, 2001). However, one of the main causes of current account deficit is the inadequacy of national savings (Çiğdem, 2017, May) (Çiğdem \& Ülgen, 2017, April). The economies of developing countries whose national savings are inadequate resort to foreign savings to finance their development. As Calvo (1998) points out, it appears that large capital inflows are behind the crises experienced in developing countries. These inflows increase financial vulnerability in economies. Kaminsky et al. (1998) and Edwards (2001) have empirically proved that high-rated permanent deficits increase the likelihood of currency crises. Several crises that are faced (Chile \& Mexico at the beginning of 1980s, Finland in 1991, England \& Norway at the end of 1980s, Mexico \& Argentina 1990s, Asian Countries at the end of 1990s, Turkey in 2001, USA in 2007, Ireland in 2008, Greece in 2010) (Baharumshah et al., 2005, Ongun, 2002), showed that it is necessary to monitor the CAD/GDP ratio as a guiding signal. Besides the CAD/GDP ratio, another fact that is required to be considered is "sustainability". Some researchers draw attention on the importance of the sustainability of current accounts deficit rather than its existence.

The concept of sustainability which started to be enounced after the second half of the 1970's, have become an issue that is needed to be seriously stressed especially from the point of countries that are struggling with foreign debt. Sustainability concept, which presents distinctness in terms of definitions and indications, at the same time, has the meaning of sustainability of the foreign debt. According to Milesi-Ferreti and Razin, sustainability is related with the demand for payment of the country in debt, and the motivation of lending of the creditor country 
(Milesi-Ferreti \& Razin, 1996a, b, c).

It is possible to group the approaches regarding the sustainability in three main subjects; (i) In the condition that current policy attitudes do not pose an obstacle regarding the solvency which is projected for the uncertain future, the said policies are sustainable (Milesi-Ferreti \& Razin, 1996c) (Corsetti \& Roubini, 1991). (ii) In a case where the current macro-financial conditions are continuing (in other words, no external crisis is experienced) and macro-financial policy changes are not made, the current deficit may be sustainable if an external crisis does not occur (Roubini-Wachtel, 1998). (iii) A current deficit which to the scale that the deficit is demanded by the foreigners to be financed, is sustainable (Milesi-Ferreti \& Razin, 1996a, b, c). In addition to this, Miles-Ferreti and Razin (1996a, b) state that the sustainability of disequilibrium may be possible to be low on conditions which; (i) Disequilibrium being high in comparison with GDP (ii) Disequilibrium originating from the decline in the national savings rate rather than the increase in the national investments and (iii) the rates of national savings being low.

It is important for the current deficit to be reduced or at least become sustainable in order for the increase in social welfare and sustainable financial growth (Karunaratne, 2010; Takeuchi, 2010; Holmes et al., 2011; Chen, 2011). From this point on, the problem of Turkey's chronic current account deficit problem in the study will be examined by applying two broken Lee and Strazicich tests. The main aim of this study is to empirically determine whether Turkey's current account deficit is sustainable. The study will first examine the development of the current account deficit in Turkey during the period 1980-2016. Following the data and methodology, the findings obtained after the analysis will be explained and these findings will be evaluated in the conclusion part.

\section{Current Account Deficit in Turkey Since 1980s}

Since the end of the 1980s, Turkey has given structural current account deficit. It is observed that after 2002, this deficit has increased significantly. Current account transactions in Turkey have been closed only five times in the post-1980 period $(1988,1989,1991,1994,1998,2001)$ with the current account surplus. The total sum of these years has been 11.2 billion dollars. On the other hand, the sum of the deficit between 2003 and 2012 is 333.5 billion dollars. 56.4\% of this deficit belongs to 2010-2012 period. The current account deficit shrank considerably due to the global crisis in 2009 , in 2010 , it recorded a very rapid growth, reaching the highest figure (-74.4 billion dollars) in 2011.

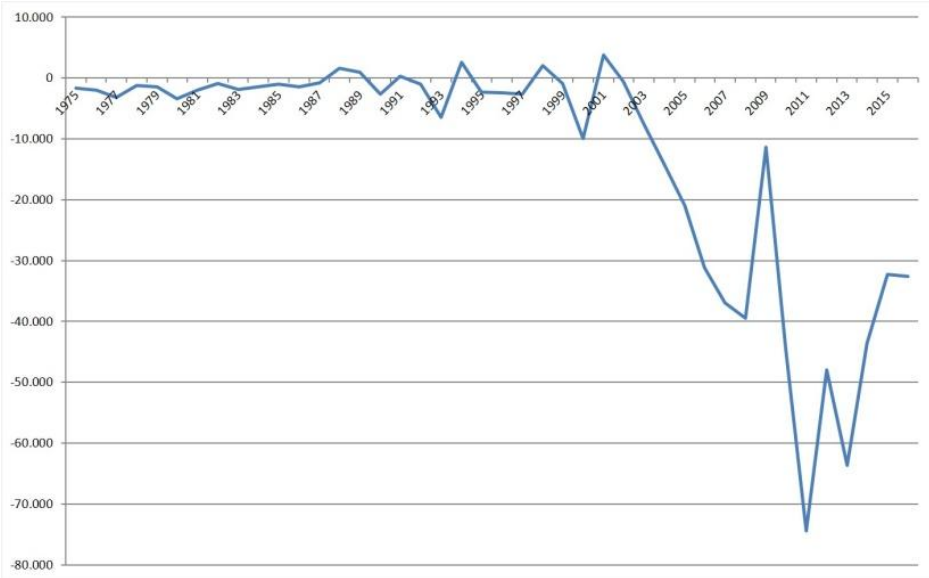

Figure 1. Current account balance in Turkey (billion dollars)

Source. IMF.

As can be seen from Figure 1, the current account deficit problem in Turkey has been abolished in 1986-1988, 1993-1994, 2000-2001 and 2008-2009 due to the economic crises experienced.

The deepening of CAD/GDP ratios before the crisis period is remarkable. According to Edwards (2001), big deficits should be a cause of concern. Edwards (2005) notes that current account deficits are unsustainable if the CAD/GDP ratio is about 6\%. Following the 1994 Mexico Crisis, the 5\% criterion set by L.Summers was widely accepted. Given that current account deficits of more than 5\% of gross domestic product are covered by hot money (short-term capital flows) or reserves, it is considered to be a major problem. These deficits should be followed closely. Before the 2001 crisis, it is seen that the ratio of CAD/GDP in 2000 was $-3.6 \%$, in the year before the crisis of $2008-5.65 \%$ in $2006-5.47 \%$ in 2007 . It was seen that this ratio constituted the bottom level of history with $-8,93 \%$ in 2011. 


\section{Data}

To investigate the current account deficit problem in Turkey, I use the ratio of current account deficit to GDP (CAD/GDP). The yearly data over the 1980-2016 period are obtained from the IMF's International Financial Statistics database.

\section{Methodology and Empirical Results}

This section analyses current account deficit in Turkey empirically.

\subsection{Unit Root Tests}

The application of unit root tests to the variables in the analyzes is the first and compulsory basic step. The regression for the $\mathrm{ADF}$ unit root test is as follows.

$$
\begin{gathered}
\Delta y_{t}=\alpha+\beta T+\phi y_{t-1}+\sum_{i=1}^{k} \quad \delta_{i} \Delta y_{t-i}+u_{t} \\
\Delta y_{t}=\alpha+\phi y_{t-1}+\sum_{i=1}^{k} \delta_{i} \Delta y_{t-i}+u_{t}
\end{gathered}
$$

With the estimation of the above equations, the existence of the unit root of the $y_{t}$ variable is tested. The T in Equation 1 shows the deterministic trend. Delayed difference terms are included in the model to ensure that the error term is not autocorreated. In Equation 1, the basic hypothesis is tested that the $y_{t}$ variable is the unit root of the alternative to the trend-stable alternative. In Equation 2, the basic hypothesis is tested that the $y_{t}$ variable is the unit root of the alternative to the stationary.

$$
H_{0}: \phi=0 \quad H_{1}: \phi<0
$$

If the $\varphi$ estimation is not different from zero, the unit root base hypothesis can not be rejected. If $\varphi<0$, the trend-stable or mean-stationary alternative hypotheses of the variable $y_{t}$ will be accepted. In the first step of my empirical analysis, the order of integration of the series is tested using Augmented Dickey Fuller (ADF) and Philips Perron (PP) unit root tests. The test results applied to the data of the CAD/GDP variable are given in Table 1.

Table 1. The results of unit root tests

\begin{tabular}{lccccc}
\hline & & & \multicolumn{3}{c}{ Critical Values } \\
\cline { 4 - 6 } & Variable & Test Statistics & \%1 & \%5 & \%10 \\
\hline ADF & CAD/GDP, level & -3.924739 & -4.234972 & -3.540328 & -3.202445 \\
PP & CAD/GDP, level & -3.893594 & -4.234972 & -3.540328 & -3.202445 \\
\hline
\end{tabular}

Note. *** represents a significance level of $1 \%$. The number of delays in the ADF tests is determined according to the Schwarz criteria. The Schwartz criteria is a stronger criterion and gives better results than the others. In the PP tests, the number of delays determined according to Newey-West Bandwith is taken. As a test format, fixed and trend equation options are used for all variables at the level value. The fixed equation option is used to obtain the first difference of the variables. MacKinnon critical values are contemplated.

According to the ADF and PP test results, the CAD/GDP series is stationary at the level for both models. The minimum LM unit root test suggested by Lee and Strazicich (2003) is used to capture a possible structural break.

\subsection{Lee-Strazicich (2004) Unit Root Test}

In the time series analysis, unit root analyzes made when structural breaks are not taken into consideration during an analysis period where structural breaks occur can give erroneous results (Perron, 1989). The main structural fracture unit root tests are; Perron (1989), Zivot-Andrews (1992), Lumsdaine-Papell (1997), Perron (1997), Ng-Perron (2001), Lee-Strazicich (2003) and Carrion-i-Silvestre et al. (2009). There are various analyzes, such as whether the break time is determined internally or externally, single, double or multiple breaks. The most advanced of these tests is Carrion-i-Silvestre et al. (2009) test and it is possible to test the stability of the series taking into consideration the structural break up to 5 pieces.

The Lee-Strazicich unit root test, which allows the existence of an internally determined structural fracture, is an LM unit root test based on two models according to the fracture (model A) and trend (model C) (Lee and Strazicich, 2004). Differently Zivot-Andrews and Lumsdaine-Papell unit root tests, according to this test which was introduced into the literature by Lee and Strazicich, structural breakages may be examined under either base hypothesis or alternative hypothesis. Lee and Strazicich's (2003) LM unit root test with two structural breaks is formulated as below:

$$
y_{t}=\delta^{\prime} Z_{t}+e_{t}, \quad e_{t}=\beta e_{t-1}+\varepsilon_{t}
$$

where $\mathrm{Zt}$ consists of deterministic terms and $\varepsilon_{t} \sim$ iid $N\left(0, \sigma^{2}\right)$. 
Model A allows for two breakages on the surface and is expressed as follows: $\mathrm{Zt}=\left[1, \mathrm{t}, D_{1 t}, D_{2 t}\right]$ '. Here, while $\mathrm{t}$ is $\mathrm{t} \geq T_{B j}+1 D_{j t}$ is equals to 1 and 0 in other situations. $T_{B j}$ value represents the breakage point. Model $\mathrm{C}$ allows for two breakages on the surface and trend and is expressed as follows: $Z_{t}=\left[1, \mathrm{t}, D_{1 t}, D_{2 t}, D T_{1 t}, D T_{2 t}\right]$ '. Here, while $\mathrm{t}$ is $\mathrm{t} \geq T_{B j}+1, D T_{j t}$ is equals to $\mathrm{t}-T_{B j}$ or becomes equal to 0 in other situations. This method includes the breakages under both null hypothesis $(\beta=0)$ and the alternative hypothesis $(\beta<1)$. In Model A (A similar method for Model $\mathrm{C}$ may be developed), hypotheses are created as follows depending on the $\beta$ coefficient:

$$
\begin{gathered}
H_{0}: y_{t}=\mu_{0}+d_{1} B_{1 t}+d_{2} B_{2 t}+y_{t-1}+v_{1 t} \\
H_{A}: y_{t}=\mu_{1}+\gamma_{t}+d_{1} D_{1 t}+d_{2} D_{2 t}+v_{2 t}
\end{gathered}
$$

Here, $v_{1 t}$ and $v_{2 t}$ are constant error terms. For $\mathrm{t}=T_{B j}+1, B_{i t}$ is equals to 1 or 0 in other situations and the $\mathrm{d}$ value is shown as $\mathrm{d}=\left(d_{1}, d_{2}\right)$ '. In Model $\mathrm{C}, D_{j t}$ expressions are added in the equation number 2 , and $D T_{j t}$ expressions are added in the equation number 3 . Equation number 2 which shows the null hypothesis contains dummy variables $\left(B_{j t}\right)$. The LM unit root test statistic is extracted from the following equation:

$$
\Delta y_{t}=\alpha^{\prime} \Delta Z_{t}+\phi \tilde{S}_{t-1}+\sum \gamma_{i} \Delta \tilde{S}_{t-i}+\mu_{t}
$$

where $\tilde{S}_{t}$ is a detrended series such that $\tilde{S}_{t}=y_{t}-\widetilde{\Psi}_{x}-Z_{t} \tilde{\delta}_{t}, \mathrm{t}=2, \ldots, \mathrm{T}$. $\tilde{\delta}$ is a vector of coefficients in the regression of $\Delta \mathrm{y}_{t}$ on $\Delta \mathrm{Z}_{t} ; \widetilde{\psi}_{X}=y_{1}-Z_{1} \tilde{\delta}$ and $y_{1}$ and $Z_{1}$ are the first observations of $Y_{t}$ and $Z_{t}$, respectively. The null hypothesis of a unit root is tested against the alternative hypothesis of trend stationarity. Structural break $(T B)$ is determined by selecting all possible break points for the minimum t-statistic as follows:

$$
L M_{t}=\inf _{\lambda} \tilde{\tau}(\lambda)
$$

where $\lambda=T_{B} / \mathrm{T}$. The critical values are tabulated in Lee and Strazicich (2003) for the two breaks case. Test statistics are of minimum in breakage points. Critical values for Model $\mathrm{C}$ are dependent on the breakage points. When the LM test statistics are greater than the critical values created by Lee and Strazicich (2003), null hypothesis shall be rejected. The denial of the null hypothesis states a non-stationary process. The results of the minimum LM unit root test with two structural breaks can be seen in Table 2.

Table 2. The results of Lee Strazicich unit root tests

\begin{tabular}{lcccccc}
\hline Series & $\boldsymbol{k}$ & $T B_{1}$ & $T B_{2}$ & $\lambda_{1}$ & $\lambda_{2}$ & Min. Test Statistic \\
\hline CAD/GDP & 3 & 1994 & 2009 & 0,405 & 0,810 & $-8,0963878$ \\
\hline
\end{tabular}

Note. $T B_{1}$ and $T B_{2}$ are the break dates, $\mathrm{k}$ is the lag length, St-1 is the coefficent on the unit root parameter. Since the series is a series of 1 year, the number of observations is less and maximum of 3 delays are used. In case of further delays, there may be a problem because the number of observations is few. The figures in parantheses are t-statistics. Critical values for the cofficient on the dummy variables follow the standard normal distribution. a, b, c denote statistical significance at $1 \%, 5 \%$ and $10 \%$ respectively. For model CC, critical values depend on the location of the breaks and come from Lee and Strazicich (2003).

The $T B_{1}$ and $T B_{2}$ columns of Table 2 show the estimated break points for CAD/GDP. The breaks in the intercept and trend for CAD/GDP in Turkey are statistically significant and occur in 1994 and 2009, in the years that are also marked by crises. (Figure 2).

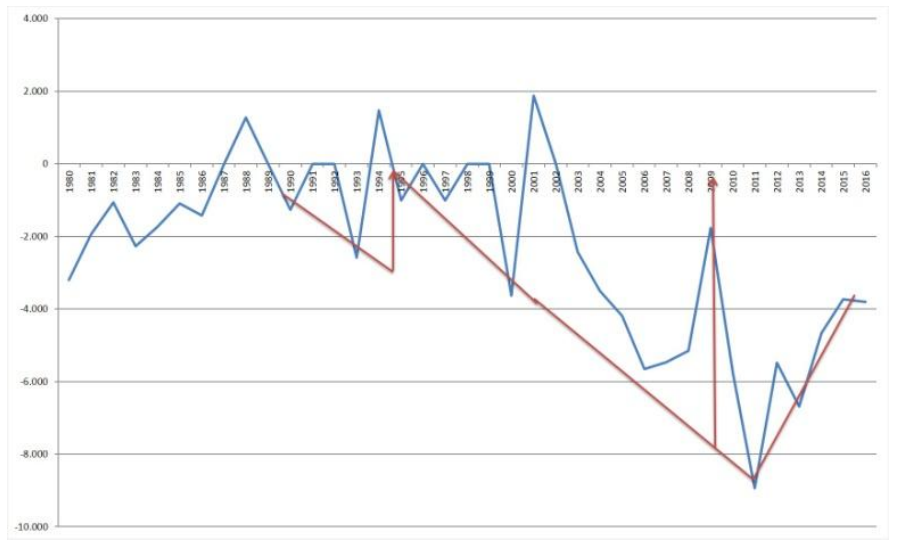

Figure 1. CAD/GDP in Turkey

Source. IMF. 
As we can see, the minimum LM test statistics are lower than the critical values at conventional significance levels for CAD/GDP in Turkey. The unit root null hypothesis could be rejected. It is a stationary process.

Table 3. Critical values of the two breaks minimum LM test

\begin{tabular}{|c|c|c|c|}
\hline \multicolumn{4}{|c|}{ (i) $L M_{T}$} \\
\hline \multirow[b]{2}{*}{$\lambda_{1}$} & \multicolumn{3}{|c|}{$\lambda_{2}$} \\
\hline & .4 & $\begin{array}{r}.6 \\
\end{array}$ & .8 \\
\hline .2 & $-6.16,-5.59,-5.28$ & $-6.40, \quad-5.74,-5.32$ & $-6.33,-5.71,-5.33$ \\
\hline .4 & - & $-6.46,-5.67,-5.31$ & $-6.42,-5.65,-5.32$ \\
\hline .6 & - & - & $-6.32,-5.73,-5.32$ \\
\hline \multicolumn{4}{|c|}{ (i) $L M_{Q}$} \\
\hline & \multicolumn{3}{|c|}{$\lambda_{2}$} \\
\hline$\lambda_{1}$ & .4 & .6 & .8 \\
\hline .2 & $-55.5,-47.9,-44.0$ & $-58.6, \quad-50.0,-44.4$ & $-57.6,-49.6,-44.6$ \\
\hline .4 & - & $-59.3,-49.0,-44.3$ & $-58.8,-48.7,-44.5$ \\
\hline .6 & - & - & $-57.5,-49.8,-44.4$ \\
\hline
\end{tabular}

Note. Critical values are at the $1 \%, 5 \%$, and $10 \%$ levels, respectively.

\section{Conclusion}

Since 1990s, the most important reason for the crises experienced in the Developing Countries is high current account deficits. The large current account deficits are considered by researchers as a warning signal for foreign exchange and financial crises, and their exceeding some thresholds of $4 \%, 5 \%$ and $6 \%$ of the CAD / GDP ratio is considered a crisis signal.

Another concept that has begun to be focused more than the existence of the current deficit is the sustainability. The current account deficit, both in terms of size and sustainability is an important criterion for evaluating the performance of an economy. Major current account deficits especially in developing countries such as Argentina, Brazil, East Asia, Mexico, Turkey, are the most important indicators of financial and foreign exchange crises. Therefore, the position of current account deficit is very important for the sustainability of economic stability.

Sustainability of the current account also means the sustainability of external debt. Therefore, it gains a special importance in terms of the countries with foreign debts. A capital flows slowdown occuring in the economies dependent on foreign savings may cause insolvency and a decrease in the average and marginal productivity of physical capital. The crises that cause insolvencies destroy human capital. Moreover, it is important how to finance current account deficit rather than its existence. According to some researchers, current account deficits financed by short-term borrowing are particularly dangerous. Some researches show that large current account deficits are a danger regardless of how they are financed; a new capital entry is needed to maintain the same deficit and it is difficult to find it at a sudden stops. In addition, in case of any deterioration / worsening in the current account balance, economic growth are damaged as a result of the subsequent exchange rate and banking crises. The researches show that any current account reversal in the current account balance has strengthened the likelihood of a break in GDP growth in developing country economies over the next 2 years. The CAD / GDP ratio in Turkey where the current account deficits are financed mainly by short-term borrowing has been maintaining at critical thresholds since 2000's. As Edwards points out, not every major current account deficit may result in a crisis, but it should be a cause of concern. It is clear that a sudden stops in capital inflows to Turkey would create problems under these conditions.

The fact that European Union has put forward its member countries' current account deficits are to be in a sustainable manner in the frame Article 3A of Maastricht Agreement is a clear indicator about the importance of sustainability. An unsustainable current account deficit causes sudden changes in exchange and interest and this may cause a bounce up in the ratio of high internal and foreign debts stocks/GDP. A sudden change in Exchange and interest rate is a reason for a crise. At the end of these changes, there may be a correction in the current account deficits, nevertheless, economic growth may be damaged. For that reason, determination of the sustainability of the current account deficits is very important especially for the policymakers. They should keep an eye on CAD/GDP ratios. Macro-economic policies conducted by the policymakers are important. In this respect, one of the essential pace is realizing structural reforms that will ease long-term foreign inflows and help take advantage of capital inflows.

In this study where the current account deficit is tested in Turkey, it is seen that the ADF and PP unit root tests 
and LM Unit Root Tests two structural breaks are consistent. According to ADF, PP Unit Root Tests, and Lee and Strazicich Unit Root Test with two structural breaks results; the unit root null hypothesis could be rejected. A finding that CAD/GDP series is stationary means that CAD/GDP have a temporary effect. On the other hand, Turkey's current account deficit is sustainable. This is important give the potential effect and flow through effects to other macroeconomic variables. This is important for its impact on other macroeconomic variables such as the value of national currency, export, inflation and Foreign Direct Investments (FDI).

Large and long-term current account deficits which reflect an imbalance situation require devaluation and tight macroeconomic policies. Especially in developing economies, the primary target of governments is to ensure economic growth and make it sustainable. However, the fact that economic growth can be achieved in the countries like Turkey that are dependent on imports in the raw materials and intermediate goods which are necessary for growth, this often results in the current account deficit problem. This may force policymakers to make a choice between economic growth and the current account deficit. There is a delicate balance in terms of policy makers here. In this context, the most effective solution, especially in the long run, structural reforms that can save domestic production from import dependency. Another macroeconomic effect of import-dependent growth outside the current account deficit is that growth does not contribute to employment growth and leads to inflation. Therefore, this provides important insights for policy makers.

In addition to structural reforms, CAD/GDP ranks should be closely monitored and policies should be developed by controlling domestic expenditures and reduce spending by controlling domestic demand. The biggest challenge for policy makers here is to reduce the current deficit without lowering economic growth. Otherwise, it is inevitable that the global economy will be adversely affected with the national economy.

\section{Acknowledgments}

The author would like to thank Associated Professor Burcu Kiran, Istanbul University, Faculty of Economics, Department of Econometrics, for her help and her valuable contributions.

\section{References}

Baharumshah, A. Z., \& Lau, E. (2005, May). Budget and Current Account Deficits in SEACEN Countries: Evidence Based on the Panel Approach. Retrieved from http://econwpa.repec.org/eps/if/papers/0504/0504002.pdf

Calvo, G. A. (1998, Nov.). Capital Flows and Capital-Market Crises: The Simple Economics of Sudden Stops. Journal of Applied Economics, 1(1), 35-54.

Carrion-i-Silvestre, J. L., Kim, D., \& Perron, P. (2009). GLS-Based Unit Root Tests with Multiple Structural Breaks Under Both the Null and the Alternative Hypotheses. Econometric Theory, 25, 1754-1792. https://doi.org/10.1017/S0266466609990326

Chen, S. W. (2011). Current Account Deficits and Sustainability: Evidence from the OECD Countries. Economic Modelling, 28, 1455-1464. https://doi.org/10.1016/j.econmod.2011.01.011

Çiğdem, G. (2017, May). Investigation of the Relationship Between Current Account Deficit and Savings in MENA Economies: An Empirical Approach. International Journal of Economics and Research (IJER), $8(3)$.

Çiğdem, G., \& Ülgen, G. (2017, April). Is the Inadequacy of National Savings the Reason of Current Account Deficit? Empirical Analysis in Fragile Eight. The Empirical Economics Letters (EEL), 16(4).

Corsetti, G., \& Roubini, N. (1991, December). Fiscal Deficits, Public Debt and Government Solvency: Evidence from OECD Countries. Journal of the Japanese and International Economies, 5, 354-380. https://doi.org/10.1016/0889-1583(91)90004-A

Edwards, S. (2001, May). Does the Current Account Matter? NBER Working Paper Series, 8275, 1-69.

Edwards, S. (2005, October). The End of Large Current Account Deficits, 1970-2002, Are There Lessons for the United States? NBER Working Paper Series, 11669.

Holmes, M. J., Panagiotidis, T., \& Sharma, A. (2011). The Sustainability of India's Current Account. Applied Economics, 43, 219-229. https://doi.org/10.1080/00036840802481876

Kaminsky, G., Lizondo, S., \& Reinhart, C. (1998). Leading Indicators of Currency Crises, IMF Staff Papers, 45, 1-48. https://doi.org/10.2307/3867328

Karunaratne, N. D. (2010). The Sustainability of Australia's Current Account Deficits-A Reappraisal After the Global Financial Crisis. Journal of Policy Modeling, 32, 81-97. 
https://doi.org/10.1016/j.jpolmod.2009.10.002

Lee, J., \& Strazicich, M. C. (2003). Minimum Lagrange Multiplier Unit Root Test with Two Structural Breaks. Review of Economics and Statistics, 85(4), 1082-1089. https://doi.org/10.1162/003465303772815961

Lee, J., \& Strazicich, M. C. (2004). Minimum LM Unit Root Test with One Structural Break. Appalachian State University Working Papers, 04/17, 1-15.

Lumsdaine, R. L., \& Papell, D. H. (1997). Multiple Trend Breaks and The Unit Root Hypothesis. The Review of Economics and Statistics, 79, 212-218. https://doi.org/10.1162/003465397556791

Milesi-Ferreti G. M., \& Razin, A. (1996a). Sustainability of Current Account Deficits. NBER Working Paper, 5467, February.

Milesi-Ferreti, G. M., \& Razin, A. (1996b). Current Account Sustainability: Selected East Asian and Latin American Experiences. NBER Working Paper, 5791, October. 13.

Milesi-Ferreti, G. M., \& Razin, A. (1996c). Current Account Sustainability. Princeton Studies in International Finance, No. 81, October.

Ng, S., \& Perron, P. (2001). Lag Length Selection and the Construction of Unit Root Tests with Good Size and Power. Econometrica, 69, 1519-1554. https://doi.org/10.1111/1468-0262.00256

Ongun, T. (2002). Türkiye'de Cari Açıklar ve Ekonomik Krizler. In Ö. F. Çolak (Ed.), Kriz ve IMF Politikaları (pp. 39-93). Alkım Yayınevi.

Perron, P. (1989). The Great Crash, The Oil Price Shock, and The Unit Root Hypothesis. Econometrica, 57(2), 1361-1401. https://doi.org/10.2307/1913712

Perron, P. (1997). Further Evidence on Breaking Trend Functions in Macroeconomic Veriables. Journal of Econometrics, 80, 355-385. https://doi.org/10.1016/S0304-4076(97)00049-3

Roubini, N., \& Wachtel, P. (1998). Current Account Sustainability in Transition Economies. NBER Working Paper No. 6468, March. 18. https://doi.org/10.3386/w6468

Schmidt, P., \& Phillips, P. C. B. (1992). LM Tests for a Unit Root in the Presence of Deterministic Trends. $\begin{array}{lllll}\text { Oxford Bulletin of Economics and } & \text { 257-287. }\end{array}$ https://doi.org/10.1111/j.1468-0084.1992.tb00002.x

Takeuchi, F. (2010). US External Debt Sustainability Revisited: Bayesian Analysis of Extended Markov Switching Unit Root Test. Japan and World Economy, 22, 98-106. https://doi.org/10.1016/j.japwor.2009.12.001

Zivot, E., \& Andrews, D. (1992, July). Further Evidence on the Great Crash, the Oil-Price Shock, and the Unit-Root Hypothesis. Journal of Business \& Economic Statistics, 10(3), 251-270.

\section{Copyrights}

Copyright for this article is retained by the author(s), with first publication rights granted to the journal.

This is an open-access article distributed under the terms and conditions of the Creative Commons Attribution license (http://creativecommons.org/licenses/by/4.0/). 